\title{
Agro-economic substantiation of the feasibility of green manured fallow in sugar beet crop rotations of the Central Chernozem Region
}

\author{
AlexanderAkimenko ${ }^{1 *}$, Vyacheslav Sviridov ${ }^{1}$, and Tatiana Dudkina ${ }^{1}$ \\ ${ }^{1}$ FSBSI «Kursk Federal Agricultural Research Center» 70b, Karl Marx St., Kursk, 305021, Russia
}

\begin{abstract}
The aim of the study is to find out the feasibility of including green manured fallow in specialized sugar beet crop rotations by comparing necessary assessment indicators with their values in a traditional crop rotation with black fallow against the background of unequal fertilization levels. The study was based on the analysis of experimental data from a long-term stationary experiment, laid out simultaneously in all fields and variants on typical chernozem in triplicate. The results are as follows: within the same fertilization levels, no significant differences in the yield of winter wheat (sugar beet precursor) were revealed, and the yield of sugar beet in a crop rotation with green manured fallow was stably higher (no more than 5 to $7 \%$ ), an increase in yield relative to the control fertilizer variant (6 tons of manure per hectare per year) against the background of a double rate of manure in combination with mineral fertilizers amounted to 21.7 to $23.4 \%$ for wheat and 14.3 to $15.6 \%$ for beets with an increase in the productivity of crop rotations (in natural and value terms) by 1.2 times, but an increase in costs by 1.3 times caused an absolute decrease in the level of profitability by 23 to $25 \%$. Differences in the assessment indicators for specific fertilization variants increased over time due to an unequal degree of soil fertility reproduction, and therefore in the fifth cycle of the crop rotation with black fallow turned out to be 1.1 to 1.3 times greater than in the green manured rotation.
\end{abstract}

Keywords: crop rotation, winter wheat, sugar beet, yield, production costs, product cost, level of profitability.

\section{Introduction}

The largest part of the cultivated area of sugar beet (Beta vulgaris $L$. v. Saccharifera) in the Russian Federation is in Central Chernozem Region. Optimal saturation of crop rotations with the crop to achieve better moisture supply and a favorable phytosanitary state of crops is 20 to $25 \%$ (return in 3-4 years) [1]. Due to the limited availability of sugar beet-suitable (field gradient $3^{\circ}$, depth of the humus horizon> $0.4 \mathrm{~m}$ ) arable land, specialized beet crop rotations are practiced with an admissibly high proportion of this crop. The central link of such crop rotations is "the predecessor - winter wheat (Tritikum vulgare L.) - sugar beet (B. vulgaris L. v. Saccharifera)". Placing sugar beets after winter wheat (T. vulgare L.) over black fallow provides the best conditions for both crops [1].

Along with the return times and predecessors fertilizers influence on the productivity of sugar beet crop rotations, the reproduction of soil fertility in them, an advantageous ratio of productivity and costs $[2,3,4]$.

Over the past two decades, biologization of agriculture in the region increased, which (along with mineral fertilizers) has a positive effect simultaneously on the reproduction of soil fertility and crop productivity $[5,6]$. Perennial leguminous grasses are the most effective means of biologization. However, their introduction into sugar beet crop rotations leads to a lengthening of the return period of beets and may limit the size of the areas under this crop. Reducing the duration of the use of perennial grasses is not economically profitable due to the high cost of their seeds. The practice of using green manured fallow is free from this disadvantage. Its positive influence on the productivity of crop rotations is confirmed by a sufficient amount of experimental material. At the same time, there is little information in the scientific literature about its economic efficiency.

The aim of the study is to find out the feasibility of introducing green manured fallow into sugar beet crop rotations in comparison with black fallow under the conditions of Central Chernozem Region. To achieve it, the following tasks were solved: to compare the yield of crops and its stability over time in crop rotations with black and green manured fallows against unequal fertilizer backgrounds; make calculations of economic efficiency; interpret the results obtained.

\section{Objects and methods}

The research was based on the analysis of experimental material obtained in a long-term stationary experiment, laid out in three replications with a systematic arrangement of variants on typical heavy loamy chernozem with humus content in the arable layer of 5.2

\footnotetext{
"Corresponding author: dt5dt@mail.ru
} 
to $5.4 \%$ and $\mathrm{pH}_{\mathrm{KCL}} 5.1$ to 5.3 units simultaneously in all fields in space and time. We compared two crop rotation designs with the same composition of crops, differing in the predecessors of winter wheat: I - black fallow, winter wheat, sugar beet, maize (Zea mays L.) for silage, barley (Nordeum sativum L.); II - green manured fallow (peas (Pisum sativum L.)), winter wheat, sugar beets, maize $(Z$. mays L.) for silage, barley (H. sativum L.). Fertilizer levels per 1 ha of crop rotation per year are as follows: $\mathrm{O} 1$ - 6 tons of manure, $\mathrm{O} 2$ - 6 tons of manure + $\mathrm{N}_{37} \mathrm{P}_{37} \mathrm{~K}_{37}$, O3 - 12 tons of manure, O4 - 12 tons of manure $+\mathrm{N}_{37} \mathrm{P}_{37} \mathrm{~K}_{37}$. The entire non-marketable part of the crop was embedded in the soil as fertilizer.

The stability of the yield over time was assessed through the coefficient of variation $V$ [the ratio of the standard deviation (root of the variance) to the arithmetic mean over the period of the yield studies (x)], expressed as a percentage (less variation corresponds to greater resistance).

To assess the productivity of crop rotations, the sum of the products of yield and the content of exchangeable energy in specific crops was divided by 5 (the number of crop rotations). Economic indicators were calculated in a similar way. The cost of the product and the resources required for its production was determined by the average actual prices for 2016-2020. Only the costs directly used for the production of the crop and attributed to the cost of production were taken into account, that is, without the cost of selling it. Byproducts and green manure fertilizers were not included in the calculation of economic efficiency.

The meteorological conditions for the growth and development of crop rotation during the years of research were characterized by great diversity. Thus, the amount of precipitation during the warm period of the year, which decisively affects the yield [7, 8, 9], varied from 29 to $136 \%$ of the climatic norm.

\section{Results and Discussion}

In terms of convergence of economic and environmental goals in modern agriculture, there are two main approaches - management based on a combination of chemical and organic fertilizers; severe restrictions on the use of mineral fertilizers. The designs of our stationary experiment generally corresponded to the indicated directions.

On the average, over the years of research, no significant differences were found in the yield of maize for silage and barley within the background of fertilizers in connection with the placement after the same predecessors (Table 1). The decrease in the yield of winter wheat over green manured fallow did not exceed $3.3 \%$, and the increase in the yield of sugar beet in the link with green manured fallow relative to its placement after winter wheat on black fallow was approximately at the same level.

The increase in fertilization levels had a significantly greater impact on the growth of yields of all crops. Relative to the control (6 t/ha) variant, its increase against the background of a combination of a single rate of manure with mineral fertilizers, a double rate of manure, a combination of the latter with mineral fertilizers was, respectively, 14.4 to $15.0 \%, 7.4$ to $7.5 \%$, 21.7 to $23.4 \%$ for winter wheat and 7.7 to $8.9 \%, 2.2$ to $4.0 \%, 14.3$ to $15.6 \%$ for sugar beets.

Table 1. Average crop yield $(\overline{\mathrm{x}}, \mathrm{t} / \mathrm{ha})$ and coefficients of its variation $(\mathrm{V}, \%)$ depending on crop rotation and fertilization level for 1992-2015.

\begin{tabular}{|c|c|c|c|c|c|}
\hline \multirow{2}{*}{ Crop } & \multirow{2}{*}{ Indicators } & \multicolumn{4}{|c|}{ Fertilization levels } \\
\hline & & $\mathrm{O}_{1}$ & $\mathrm{O}_{2}$ & $\mathrm{O}_{3}$ & $\mathrm{O}_{4}$ \\
\hline \multirow{4}{*}{$\begin{array}{l}\text { Winter } \\
\text { wheat }\end{array}$} & \multirow{2}{*}{$\overline{\mathrm{x}}$} & 3.67 & 4.22 & 3.94 & 4.53 \\
\hline & & 3.60 & $\overline{4.12}$ & 3.87 & $\overline{4.38}$ \\
\hline & \multirow{2}{*}{$\mathrm{V}, \%$} & 25.4 & 23.1 & 18.4 & 19.9 \\
\hline & & $\overline{23.5}$ & $\overline{22.4}$ & $\overline{19.0}$ & $\overline{20.9}$ \\
\hline \multirow{4}{*}{ Sugar beet } & \multirow{2}{*}{$\overline{\mathrm{x}}$} & 35.0 & 38.1 & 36.4 & 41.0 \\
\hline & & 36.6 & $\overline{39.4}$ & $\overline{37.4}$ & $\overline{42.3}$ \\
\hline & \multirow{2}{*}{$\mathrm{V}, \%$} & 19.9 & 20.0 & 15.4 & 14.2 \\
\hline & & 18.0 & $\overline{19.3}$ & $\overline{15.1}$ & 13.7 \\
\hline \multirow{4}{*}{$\begin{array}{l}\text { Maize for } \\
\text { silage }\end{array}$} & \multirow{2}{*}{$\overline{\mathrm{x}}$} & 27.4 & 29.9 & 28.3 & $\underline{31.0}$ \\
\hline & & $\overline{28.1}$ & $\overline{30.1}$ & $\overline{28.7}$ & $\overline{31.6}$ \\
\hline & \multirow{2}{*}{$\mathrm{V}, \%$} & 22.0 & $\underline{21.2}$ & $\underline{16.9}$ & $\underline{17.6}$ \\
\hline & & 20.7 & 20.1 & $\overline{17.4}$ & $\overline{17.7}$ \\
\hline \multirow{4}{*}{ Barley } & \multirow{2}{*}{$\overline{\mathrm{x}}$} & 3.22 & 3.30 & 3.24 & 3.92 \\
\hline & & 3.27 & $\overline{3.32}$ & $\overline{3.19}$ & $\overline{3.88}$ \\
\hline & \multirow{2}{*}{$\mathrm{V}, \%$} & 21.1 & 19,8 & 14,9 & 15.8 \\
\hline & & $\overline{19.9}$ & $\overline{19.6}$ & $\overline{15.5}$ & $\overline{16.3}$ \\
\hline
\end{tabular}

Note: above and below the line, respectively, in crop rotations with black and green manured fallows.

The stability of crop yields, regardless of a fallow type in crop rotations, decreased in the following order: sugar beet and barley, maize for silage, winter wheat. The large variation in the yields of the latter is associated with their dependence not only on precipitation during the growing season, but also on the conditions for obtaining timely seedlings in previous autumn

The increase in fertilization levels contributed to a marked decrease in the coefficient of variation, due to the effect of fertilizers on the partial mitigation of the dependence on the weather [10]. It was minimal in the variant of the double rate of manure, which is consistent with the conclusion of other studies that the organic farming system can provide greater annual stability of yield and income [11]. However, stability in this case is combined with productivity not for all crops and crop rotations [12].

The absence of noticeable differences in yield depending on crop rotation against the same fertilizer backgrounds led to almost the same productivity of arable land, which, in connection with fertilizers, increased in the following order: single manure rate, double manure rate, single and double manure rates in combination with mineral fertilizers (Table 2 ). The beneficial effects of fertilizers increased as the duration of the studies increased. Thus, in the fifth (last) rotation cycle compared to the first one, the increase in productivity relative to the control in the variants of a single rate of manure with mineral fertilizers, a double rate of manure, the combination of the latter with mineral fertilizers was large, respectively, in $1.7 ; 1.9 ; 2.4$ 
times in a crop rotation with black and $1.2 ; 4.3 ; 2.1$ times in a crop rotation with green manured fallow (Fig.). It should be noted that the increase in the productivity of crop rotations in the most fertilized variant turned out to be greater than the sum of the effects of doubling the manure rate and combining the control variant with mineral fertilizers.

Table 2. Productivity of crop rotations depending on the duration of research and fertilization, $\mathrm{GJ} * \mathrm{ha}^{-1} *$ year $^{-1}$.

\begin{tabular}{|c|c|c|c|c|}
\hline \multirow{2}{*}{ Crop rotations } & \multicolumn{5}{|c|}{ Fertilizer variants } \\
\cline { 2 - 5 } & $\mathrm{O}_{1}$ & $\mathrm{O}_{2}$ & $\mathrm{O}_{3}$ & $\mathrm{O}_{4}$ \\
\hline \multicolumn{6}{|c|}{1 st rotation cycle } \\
\hline I & 64.2 & 68.0 & 65.7 & 69.1 \\
\hline II & 65.0 & 69.1 & 65.3 & 70.3 \\
\hline \multicolumn{6}{|c|}{ Last (5th) rotation cycle } \\
\hline I & 55.6 & 62.0 & 58.5 & 67.4 \\
\hline II & 58.0 & 62.9 & 59.3 & 68.8 \\
\hline Average for $1992-2015$ \\
\hline I & 57.8 & 63.8 & 60.3 & 68.7 \\
\hline
\end{tabular}

Note: I and II are crop rotations with black and green manured fallows, respectively.

The main part of cash costs for production consisted of material costs for seeds, fertilizers, oil products, as well as for the maintenance of fixed assets, wages, and depreciation. The share of costs for reproduction of soil fertility in the structure of total costs increased as the level of fertilization increased from $7.7 \%$ in the control to $24.3 \%$ in the variant of combining a double rate of manure with mineral fertilizers. Insignificant fluctuations in costs over the years are associated with their change for harvesting depending on the productivity of crop rotations in specific years (Table 3 ).

The cost of production in both crop rotations increased in the following order: a doubled manure rate, a combination of single and double manure rates with mineral fertilizers. The increase in fertilizer costs outpaced the increase in production in value terms. If the total production costs against the most fertilized background compared to the control variant were 1.3 times higher, then the similar ratio in the cost of production was lower and increased from 1.1 in the first to 1.2 times in the fifth rotation cycle.

In recent years, there has been an increase in scientific and practical interest in stabilizing the profitability (profitability) of agricultural enterprises in connection with the instability of meteorological conditions $[7,13,14]$. Income is interconnected with the cost of products and the cost of producing them.

Due to the uneven distribution of precipitation, the conditions for each particular crop were in different degrees favorable or unfavorable over the years, and on the average (with the exception of the fourth) in terms of crop rotation cycles turned out to be close to the climatic norm. Therefore, for four rotations out of five, fluctuations in the cost of production and income were insignificant, and in the fourth rotation cycle, where the dry conditions of 2010 were reflected in subsequently, the cost of production and income decreased by 10.6 and $17.1 \%$, respectively, relative to the average long-term values.

The cost of production in the green manured crop rotation was slightly higher, but the costs in the field of black fallow were lower, which led to a slightly better value of the level of profitability in the latter case. The increase in the level of fertilization influenced the decrease in the level of profitability in the most fertilized variant relative to the control one 1.3 times in both crop rotations.

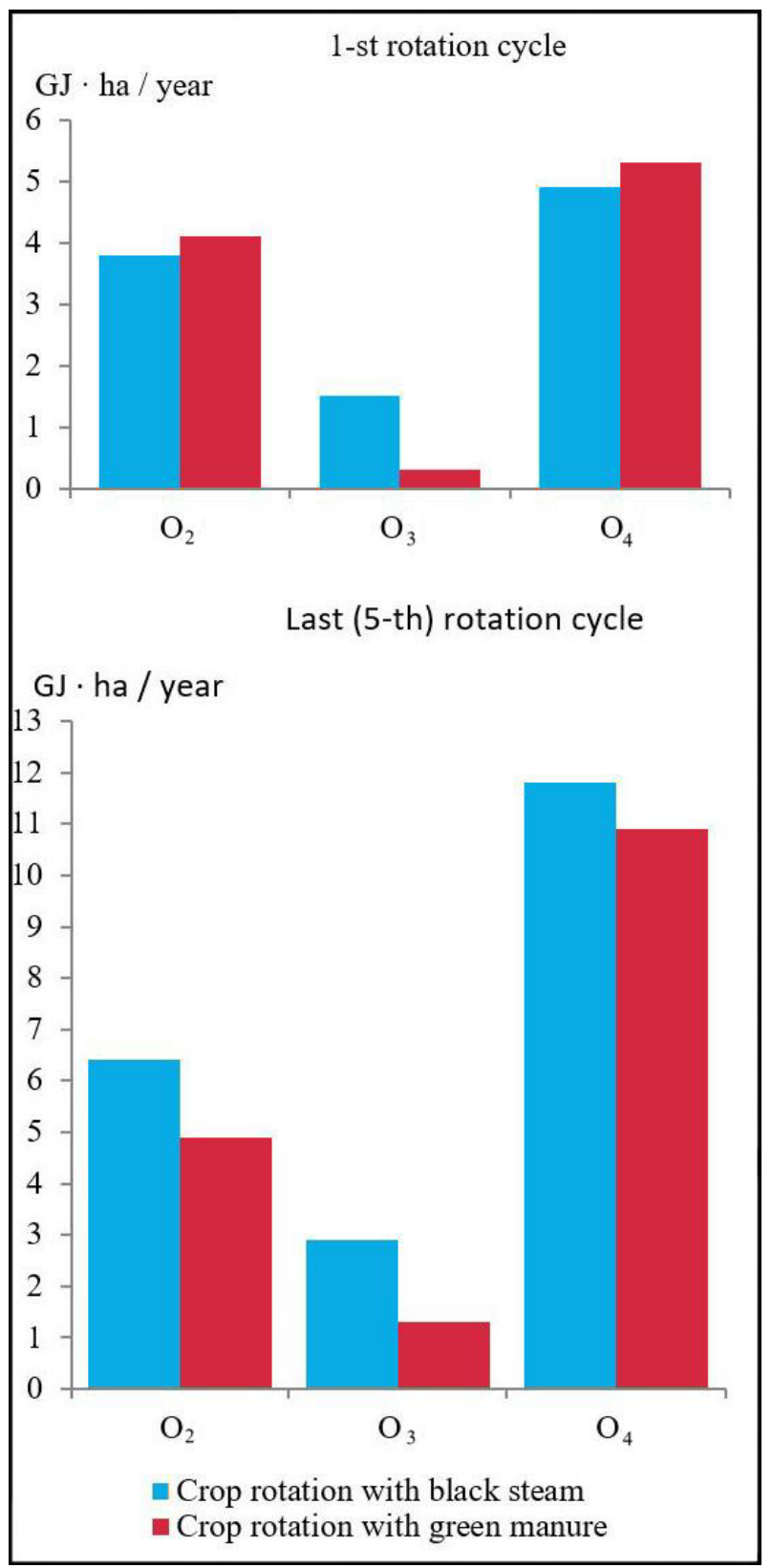

Fig 1. Increases in the productivity of crop rotations due to fertilizers in comparison with a poorly fertilized (O1) background.

Table 3. Economic efficiency of crop rotations depending on the level of fertilization, per 1 ha per year. 


\begin{tabular}{|c|c|c|c|c|}
\hline 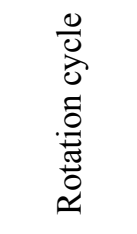 & 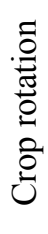 & 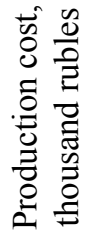 & 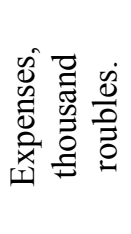 & 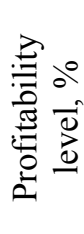 \\
\hline \multirow{4}{*}{1} & \multirow[t]{2}{*}{ I } & 49.80 & 24.50 & $\frac{103.3}{77.2}$ \\
\hline & & 53.76 & 30.32 & 77.3 \\
\hline & \multirow{2}{*}{ II } & 50.70 & 25.54 & 98.5 \\
\hline & & 54.36 & 31.00 & 75.4 \\
\hline \multirow{4}{*}{2} & \multirow{2}{*}{ I } & 45.30 & $\underline{22.40}$ & 102.2 \\
\hline & & 52.20 & 29.80 & 75.2 \\
\hline & \multirow{2}{*}{ II } & $\underline{46.98}$ & $\underline{23.84}$ & $\underline{97.1}$ \\
\hline & & 52.02 & 30.12 & $\overline{73.3}$ \\
\hline \multirow{4}{*}{3} & \multirow{2}{*}{ I } & 45.78 & 23.00 & 99.0 \\
\hline & & 53.52 & 30.94 & 73.0 \\
\hline & \multirow{2}{*}{ II } & $\underline{47.52}$ & $\underline{24.46}$ & 94.3 \\
\hline & & 54.48 & 31.08 & 75.3 \\
\hline \multirow{4}{*}{4} & \multirow{2}{*}{ I } & 40.12 & 20.20 & $\underline{98.6}$ \\
\hline & & 49.98 & 30.94 & 61.5 \\
\hline & \multirow{2}{*}{ II } & 40.36 & 21.32 & $\underline{89.5}$ \\
\hline & & 50.04 & 30.98 & 61.5 \\
\hline \multirow{4}{*}{5} & \multirow{2}{*}{ I } & 43.08 & 21.71 & 98.4 \\
\hline & & 53.40 & 30.34 & 76.0 \\
\hline & \multirow{2}{*}{ II } & $\underline{45.06}$ & 23.36 & 92.9 \\
\hline & & 54.12 & 31.10 & 74.0 \\
\hline \multirow{4}{*}{ Average } & \multirow{2}{*}{ I } & 44.87 & $\underline{22.58}$ & 98.7 \\
\hline & & 52.58 & 29.90 & 75.9 \\
\hline & \multirow{2}{*}{ II } & 45.92 & 23.40 & 96.2 \\
\hline & & 52.99 & 30.17 & 75.6 \\
\hline
\end{tabular}

Note. Above and below the line, respectively, at the lowest (6 tons of manure per hectare) and the highest (12 tons of manure + N37P37K37 per hectare) fertilization levels.

It is fundamentally important to note the relative increase over time in the differences in the cost of production for variants with contrasting fertilization rates from 8.0 to $7.2 \%$ in the first rotation cycle to 17.2 to $15.4 \%$ in the fifth rotation cycle. This increase in the crop rotation with black fallow on the average over the years of research turned out to be 1.1 times greater in comparison with the green manured crop rotation. The reason for this increase is not at all the accumulation of a positive effect due to fertilizers, but in the unequal degree of the use of the initial soil fertility. Thus, due to the negative nitrogen balance, the average annual loss of humus in the crop rotation with black fallow was 1.8 times higher than in the green manured rotation.

A smaller decrease in the yield of all crops in the control (in terms of fertilization) variant of the experiment relative to the most fertilized variant in the green manure crop rotation contributed to a lesser loss of arable land productivity in value terms relative to the crop rotation with black fallow in the last rotation cycle by $13.5 \%$ and by $9.5 \%$ on the average over the study period (Table 4) due to the positive effect of green fertilizer on the reproduction of soil fertility. This statement was confirmed by the fact that, with the insignificant contribution of green manure fallow to the relative increase in the cost of production (increased from 1.8 and $1.1 \%$ in the first rotation to 4.6 and $1.3 \%$ in the fifth, respectively, against the control and most fertilized backgrounds), the decrease in productivity in value terms in the crop rotation with black fallow for the indicated periods it turned out to be 1.2 and 1.5 times higher.

Table 4. Relative decrease in crop rotations of yield, productivity and cost of production in the poorly fertilized variant in comparison with the most fertilized one, (\%).

\begin{tabular}{|c|c|c|c|c|}
\hline \multirow{2}{*}{ Crop rotation* } & \multirow{2}{*}{ Indicators } & \multicolumn{3}{|c|}{ Rotation cycles } \\
\hline & & 1 & 5 & Average \\
\hline I & \multirow{2}{*}{$\begin{array}{r}\text { Crop yield: } \\
\text { winter } \\
\text { wheat }\end{array}$} & 14.3 & 22.4 & 18.4 \\
\hline II & & 12.9 & 17.5 & 15.2 \\
\hline I & \multirow{2}{*}{$\begin{array}{l}\text { sugar } \\
\text { beets }\end{array}$} & 4.9 & 22.2 & 14.6 \\
\hline II & & 3.7 & 20.4 & 12.5 \\
\hline $\mathrm{I}$ & \multirow{2}{*}{$\begin{array}{c}\text { maize } \\
\text { for silage }\end{array}$} & 8.0 & 14.9 & 11.6 \\
\hline II & & 6.0 & 11.8 & 11.0 \\
\hline I & \multirow{2}{*}{ barley } & 7.5 & 16.2 & 15.8 \\
\hline II & & 6.9 & 14.9 & 13.7 \\
\hline $\mathrm{I}$ & \multirow{2}{*}{$\begin{array}{l}\text { Arable land } \\
\text { productivity }\end{array}$} & 7.1 & 17.5 & 15.9 \\
\hline II & & 7.5 & 15.6 & 15.3 \\
\hline $\mathrm{I}$ & \multirow[t]{2}{*}{ Production cost } & 2.0 & 19.3 & 14.7 \\
\hline II & & 6.7 & 16.7 & 13.3 \\
\hline
\end{tabular}

* I and II - crop rotations with black and green manured fallow.

\section{Conclusion}

Based on the absence of significant differences in the yield and productivity of arable land (in natural and value terms) depending on the type of crop rotation with the same fertilization rates, the positive effect of increasing fertilization levels on the stability of yields due to weather fluctuations and the contribution of green fertilizer to ensuring the stability of agronomic and economic indicators over time, it can be argued about the advisability of including green manure fallow in the sugar beet crop rotations of Central Chernozem Region, which will ensure the convergence of economic and environmental goals in agriculture.

The work was carried out within the framework of the state assignment of the Federal State Budgetary Scientific Institution "Kursk Federal Agricultural Research Center" on topic No. 06322019-0013.

\section{References}

1. V.M. Dudkin, Intensive sugar beet crop rotations in Central Chernozem Zone, Moscow, Agropromizdat (1990)

2. H. Reineke, N. Stockfisch, B. Märländer, Eur. J.1 Agron., 45, 27 (2013)

3. P. Götze, J. Rücknagel, O. Christen, Eur. J. Agron., Jan., 82, 50 (2017)

4. A.P. Karabutov, S.I. Tyutyunov, V.D. Solovichenko, EurAs. J. BioSci., 13, 1317 (2019).

5. N.N. Khryukin, A.V. Dedov, M.A. Nesmeyanova, Fert., 4, 52 (2017) 
6. A.S. Akimenko, N.V. Dolgopolova, V.G. Vavin, T.A. Dudkina, L.I. Sadykova, Achiev. Sci. \& Technol. Agribus., 34, 16-20 (2020)

7. R. Wang, L.C. Bowling, K.A. Cherkauer, Agr. \& Forest Meteorol., 216, 141 (2016)

8. S.K. Sweet, D.W. Wolfe. A. DeGaetano, R. Benner, Agr. and Forest Meteorol., 247, 571 (2017)

9. Y. Kuwayama, A. Thompson, R. Bernknopf, R. Zaitchik, P. Vail, Amer. J. Agr. Econ., 101, 193 (2019)

10. F. Morari, V. Zanella, L. Sartori, G. Visioli, P. Berzaghi, G. Mosca, Precis. Agr., 19, 257 (2018)

11. R. Eeswaran, A. Nejadhashemi, S. Miller, Climate Risk Manag., 32 (2021)

12. S. González-García, F. Almeida, M.T. Moreira, M. Brandão, Sci. Total Environ., 770 (2021)

13. A. Meyer-Aurich, Y.N. Karatay. Agr. Syst., 173, 130 (2019)

14. L. Zhang, W. Zhang, Z. Cuia, Y. Hu, U. Schmidhalter, X. Chena, J. Clean. Prod., 311 (2021) 